\title{
A NEW SPECIES OF GAYLORDIA PAULA COUTO (MAMMALIA, METATHERIA) FROM ITABORAÍ, BRAZIL
}

\author{
ÉDISON VICENTE OLIVEIRA \\ Departamento de Geologia, Centro de Tecnologia e Geociências, UFPE, Av. Acadêmico Hélio Ramos s/n, \\ 50740-530, Recife, PE, Brazil.vicenteedi@gmail.com \\ FRANCISCO J. GOIN \\ División Paleontología Vertebrados, Museo de La Plata, CONICET, Paseo del Bosque s/n, B1900FWA \\ La Plata, Provincia de Buenos Aires, Argentina.fgoin@fcnym.unlp.edu.ar
}

\begin{abstract}
We describe a new metatherian of the genus Gaylordia Paula Couto, from the early Eocene Itaboraí Basin, Brazil. This new species (estimated body mass $\sim 60-90.9 \mathrm{~g}$ ) is based on lower and upper dentition elements and is characterized by a more plesiomorphic dental morphology with respect to G. macrocynodonta Paula Couto (with a larger body mass, estimated in 74-103 $\mathrm{g}$ for large individuals or males). The species G. doelloi Marshall, represented by small individuals or females, is regarded a junior synonym of G. macrocynodonta. A phylogenetic analysis as well as details of the occlusal surface of its upper and lower molars suggests that Gaylordia is closely related to the Pucadelphyidae, a non-marsupial "ameridelphian" group previously recorded at the early Paleocene locality of Tiupampa, Bolivia.
\end{abstract}

Key words: systematics, Paleogene, Mammalia, Metatheria, body mass, Brazil.

RESUMO - Descreve-se um novo marsupial basal do gênero Gaylordia Paula Couto, do Eoceno inicial da bacia de Itaboraí, Brasil. Esta nova espécie (massa corporal estimada $\sim 60-90.9 \mathrm{~g}$ ) está baseada na dentição superior e inferior, e é caracterizada por uma morfologia dentária mais plesiomórfica em relação a G. macrocynodonta Paula Couto (cuja maior massa corporal é estimada em 74-103 g para grandes indivíduos ou machos). A espécie G. doelloi Marshall, representada por indíviduos pequenos ou fêmeas, é considerada um sinônimo junior de G. macrocynodonta. Uma análise filogenética, bem como detalhes da superfície oclusal de seus molares superiores e inferiores sugerem uma relação próxima de Gaylordia aos Pucadelphyidae, um grupo de ameridélfios não marsupiais previamente registrados no Paleoceno inicial da localidade de Tiupampa, Bolivia.

Palavras-chave: sistemática, Paleógeno, Mammalia, Metatheria, massa corporal, Brasil.

\section{INTRODUCTION}

The early Paleogene Itaboraí fauna in eastern Brazil represents one of the richest localities of metatherian diversity from the whole Cenozoic of South America. A taxonomic revision of the Itaborai taxa is crucial to the understanding of early metatherian phylogeny, in particular those traditionally referred to the "Didelphimorphia" (Marshall et al., 1990). This aspect is of particular importance taking in account that recent phylogenetic studies involving some Paleogene taxa (e.g. Herpetotherium Cope, 1873 and Peradectes Matthew \& Granger, 1921, previously referred to the Didelphidae and Peradectidae, respectively), supported their exclusion from the crown-group Marsupialia (Sánchez-Villagra et al., 2007; Beck, 2012; Beck et al., 2014; Engelman \& Croft, 2014, but see Horovitz et al., 2009). In this context, the closer relationship of several Itaboraí metatherians with respect to crown-group Marsupialia, especially to "Didelphimorphia", has been a topic of discussion (Goin, 2003; Forasiepi \& Rougier, 2009; Ladevèze \& Muizon, 2010; Oliveira \& Goin, 2011).
Here we review the type material and undescribed specimens of Gaylordia, a Paleogene genus previously assigned to the Didelphidae (Marshall et al., 1990), which allowed the recognition of several new cranial and dental characters. This genus is one of the few Itaboraí taxa defined on the basis of a skull and includes a large hypodigm (Paula Couto, 1952; Marshall, 1987; Oliveira, 1998). In addition, in their comprehensive study of metatherian postcranials Szalay (1994) and Szalay \& Sargis (2001) referred to representatives of this genus several isolated postcranial materials only with Gaylordia. The new species of Gaylordia here described is based on a previously unreported upper dentition and on dentaries (including lower molars) previously referred to Derorhynchus singularis Paula Couto. 1952 and Marmosopsis juradoi Paula Couto, 1962 (Marshall, 1987). Morphological details of the upper and lower molars are described for the first time for Gaylordia.

The type species (Gaylordia macrocynodonta) was erected by Paula Couto (1952) on the basis of an anterior part of a skull with incomplete, worn teeth. Later, Paula Couto (1962) 
recognized a new genus and species, Xenodelphis doelloi, and finally he described an additional species of Gaylordia, G. mendesi Paula Couto, 1970. The type materials of $X$. doelloi and G. mendesi were reviewed by Marshall (1987), who concluded that both are inseparable in size and structure and suggested that they should be regarded as synonyms, establishing the combination G. doelloi. Later, Marshall et al. (1990) included Gaylordia within Didelphidae: Eobrasiliinae, along with other early Paleogene taxa such as the Itaboraian Didelphopsis Paula Couto, 1952, and Eobrasilia Simpson, 1947 and the Tiupampian Tiulordia Marshall \& de Muizon, 1988. Goin (2003) and later Oliveira \& Goin (2011) transferred Didelphopsis to Sternbergiidae, ruling out closer affinities between Eobrasilia and Gaylordia. The genus Gaylordia is of special interest regarding its affinities with the early Paleocene Tiupampian genus Tiulordia, from the locality of Tiupampa, Bolivia (Muizon, 1991; Muizon \& Brito, 1993; Oliveira \& Goin, 2011). Previous works recognize the Pucadelphyidae as encompassing Pucadelphys Marshall \& de Muizon, 1988 and Andinodelphys Marshall \& de Muizon, 1988 (Muizon, 1998; Ladevèze \& Muizon, 2010). Goin (2003) suggested the inclusion in this family of Mizquedelphys Marshall \& de Muizon, 1988 and Incadelphys. In addition, a recent phylogenetic study has considered the Tiupampian genus Mayulestes Muizon, 1994 as a member of Pucadelphyidae (Engelman \& Croft, 2014).

\section{MATERIAL AND METHODS}

All studied materials come from the Itaboraí fossil locality in southeastern Brazil (Figure 1). Details on the geology and age were summarized in previous works (e.g. Medeiros \& Bergqvist (1999), Oliveira \& Goin (2011). More recently, an absolute Ar/ Ar dating of a tuff in the (also Itaboraian-aged) levels of Las Flores, in central Patagonia, supported an early Eocene age for the Itaboraian SALMA (see Woodburne et al., 2014).

Institutional abbreviations. AMNH, American Museum of Natural History, New York, USA; MCN, Museu de Ciências Naturais, Fundação Zoobotânica do Rio Grande do Sul, Porto Alegre, Brazil; MCT (ex DGM), Museu de Ciências da Terra, Rio de Janeiro, Brazil; MN, Museu Nacional/Universidade Federal do Rio de Janeiro, Rio de Janeiro, Brazil; UFPE, Universidade Federal de Pernambuco, Recife, Brazil.

Anatomical abbreviations. C1, upper canine; c1, lower canine; p1, p2, p3, lower premolars; M1/m1, M2/m2, M3/ m3, M4/m4, upper and lower molars; StA, StB, StC, StD, StE, stylar cusps. Molar cusp and crest nomenclature follows Oliveira \& Goin (2011).

Abbreviations for descriptive statistics. In table 1 (dental measurements); L, maximum anteroposterior length and W, maximum labiolingual width. An asterisk (*) after some measurements indicates that they are approximate.

Other abbreviations. g, grams; CI, consistency index; RC, rescaled consistency index; RI, retention index; SALMA, South American Land Mammal Age.

Body mass. Body mass estimates (in g) were calculated for the species of Gaylordia following regression equations for upper and lower molars crown area by multiplying

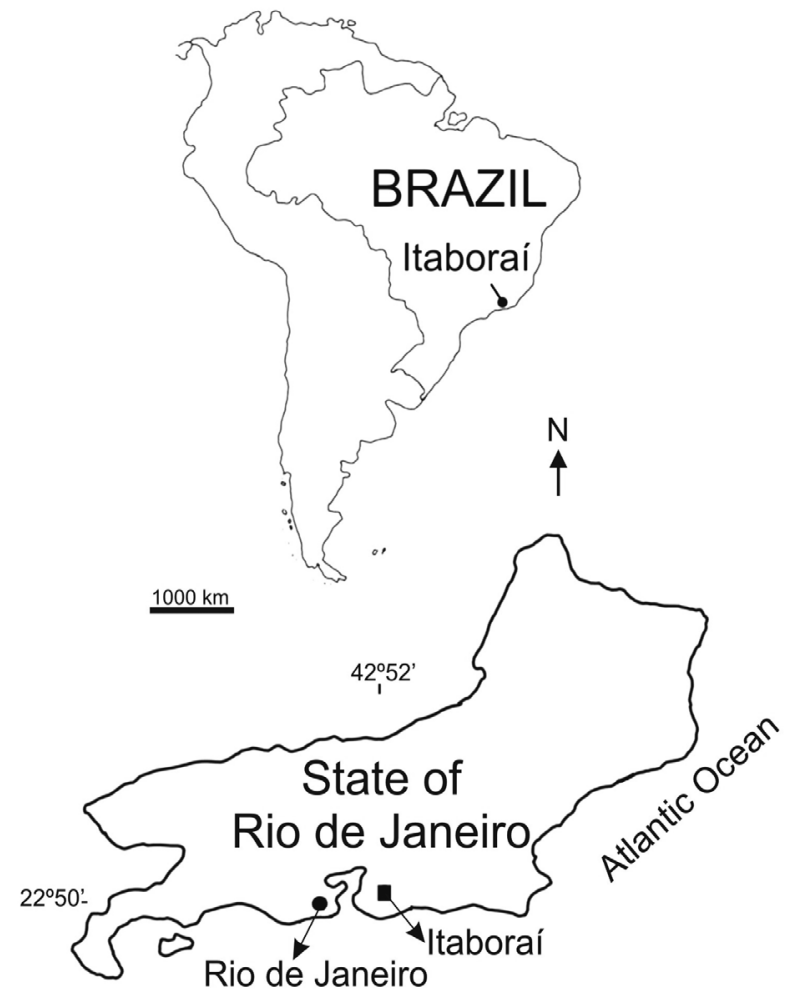

Figure 1. Location map showing the region of the Itaboraí Basin.

maximum length and maximum width (lengthxwidth) from two different datasets provided by Gordon (2003): the Didelphidae (Caluromys excluded) and pooled Didelphidae and Dasyuridae.

\section{Phylogenetic analysis}

In order to determine the position of Gaylordia within the Metatheria, we performed a maximum parsimony analysis based on the morphological matrix of Beck (2012) and Beck et al. (2014). This morphological matrix has been modified from previous studies (Horovitz \& Sánchez-Villagra 2003; Sánchez-Villagra et al. 2007; Beck et al. 2008b; Horovitz et al. 2008, 2009; Abello \& Candela 2010; Beck, 2012). Parsimony analysis of the matrix was carried out using the heuristic search algorithm of PAUP* 4.0b 10 (Swofford, 2002) with an initial search of 2000 replications. The morphological matrix comprised 262 characters and 38 taxa. We analyzed two hypotheses: the first analysis including craniodental characters of the present paper and petrosal type I from Ladevèze \& Muizon (2010); the second analysis including craniodental and petrosal type VI characters from Ladevèze \& Muizon (2010). Coding of the morphological characters from the first analysis on the craniodental and petrosal type I for Gaylordia is ? ? ? ? ? ? ? ? (10) ? ? ? ? ? ? ? ? (20)

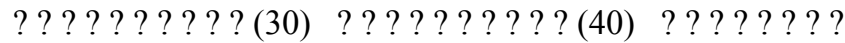
??(50) ????????? ?(60) ??????????? ? ? (70) ?? ?? ?? ?? ?(80) ? ? ? ? ? ? ? ? (90) ? ? ? ? ? ? ?

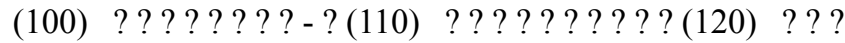
??????(130) ?????????(140) ??????? 00 
(150) $0210011 ? 12(160) 2 ? ? ? 1201 ? 0(170) 0$ ??? 1000 ? $1(180) 0$ ?? ?? ? ? ? (190) ? ? ? ? ? 0 ?? ?(200) ?? ?? ????? (210) ?? ? ? ? ? ? 2 (220) ?? ?02?-1101(230) $0101000101(240) \quad 10001$ 11001 (250) - 111110 ?? 1(260) ?? (262). Coding of the morphological characters from the craniodental and petrosal type VI differs from the first analysis in the following characters: 228 (state 0), 234 (state 0), 235 (-inapplicable), 236 (state 1), 239-242 (unknown), 245 (state 0), 247 (unknown), 249-253 (unknown).

\section{SYSTEMATIC PALAEONTOLOGY}

\author{
Class MAMMALIA Linnaeus, 1758 \\ Infraclass METATHERIA Huxley, 1880 \\ Order INCERTAE SEDIS
}

Genus Gaylordia Paula Couto, 1952

Type species. Gaylordia macrocynodonta Paula Couto, 1952.

1952 Gaylordia Paula Couto, p. 16, fig. 16. 1962 Gaylordia Paula Couto, p. 151, fig. 9. 1962 Xenodelphis Paula Couto, p. 160.

1970 Xenodelphis Paula Couto, p. 21, fig. 1.

1970 Gaylordia Paula Couto, p. 22, figs. 2, 3.

1987 Gaylordia Marshall, p. 103, figs. 12-18.

Revised diagnosis. Small metatherian with body mass estimated between 20.8 and $103 \mathrm{~g}$ and characterized by the following combination of features: skull with relatively short rostrum, relatively short dentary, lower premolars subequal in size, $\mathrm{p} 2$ bulbous and with a well-developed posterior accessory cusp, lower molars with elevated trigonids relative to talonids, m2-3 with metaconid anteriorly displaced in relation to protoconid, very low paraconid in relation to metaconid, long preprotocristid, talonids subequal to or narrower than trigonids and progressively shortened from $\mathrm{m} 1$ 4, small entoconids, anterior cingulid well-developed in m1-4, M1-3 wider than long, with large StC and anteroposteriorly compressed protocones, and conular crests absent. Differs from Pucadelphys in the smaller StA (parastyle), less developed conules and lower molars with shorter talonids. Differs from Tiulordia in having the $\mathrm{StC}$ undivided, $\mathrm{m} 2$ with a less compressed trigonid and a more robust and acute hypoconid, so that the cristid obliqua ends slightly labial to a point below the postprotocristid notch. Differs from Mizquedelphys and Incadelphys in its much greater StC on M2 and M3, smaller StA, and less developed conules; the protocone in Gaylordia is more expanded lingually than in Incadelphys. Differs from Andinodelphys (a questionable Pucadelphyidae) in having the StC undivided, V-shaped centrocrista instead straight, absence of conular crests on the metaconule, expanded protocone, less developed anterior cungulum, and absence of cutting edge crests. Differs from Mayulestes in having the stylar shelf less developed in width, paracone and metacone twinning (i.e. the paracone and the metacone are coalescent at their bases), talonid shorter, paraconid more reduced, and the hypoconulid lower in relation to hypoconid.

\section{Gaylordia macrocynodonta Paula Couto, 1952}

(Figures 2, 3A,B; Table 1)

1962 Xenodelphis doelloi Paula Couto, p. 160. 1970 Xenodelphis doelloi Paula Couto, p. 22, fig. 1. 1970 Gaylordia mendesi Paula Couto, p. 23, fig. 3. 1987 Gaylordia doelloi Marshall, p. 104, figs. 12-13.

Holotype. DGM 329-M, incomplete rostrum with right P2$\mathrm{M} 2$, root of $\mathrm{C} 1$, roots of $\mathrm{P} 1$, and incomplete $\mathrm{M} 3$; left $\mathrm{C} 1$, roots of $\mathrm{P} 1-\mathrm{P} 3$, worn $\mathrm{M} 1$, anterolabial root of $\mathrm{M} 2$, and root of M3; and an incomplete left dentary with $\mathrm{p} 3$ and $\mathrm{m} 1$, roots of $\mathrm{p} 1-2$, and crowns of $\mathrm{m} 2-3$.

Hypodygm. The holotype and AMNH 49801, an incomplete right dentary with $\mathrm{p} 2-\mathrm{m} 2$ and alveoli of $\mathrm{m} 3$; DGM 186-M, left dentary with $\mathrm{p} 3-\mathrm{m} 1$ and alveoli for the rest of the molar teeth; DGM 925-M, left dentary with complete p1-m1; MCT 2385-M (DGM 646-M), incomplete left dentary with m1-2 and roots of $\mathrm{m} 3-4$; MN 1355-V, incomplete right dentary with alveoli of $\mathrm{p} 1$ and complete $\mathrm{p} 2-\mathrm{m} 4$; MN 1357-V, left dentary with $\mathrm{p} 3$ and $\mathrm{m} 3$, and alveoli of $\mathrm{p} 1-2, \mathrm{~m} 1-2$ and $\mathrm{m} 4$; MN 1358$\mathrm{V}$, right dentary with $\mathrm{p} 3$, alveoli of p1-2 and of m1-4; MN 1366-V, left dentary with $\mathrm{m} 1$, alveoli of $\mathrm{p} 2-3$ and of $\mathrm{m} 2-4$. Also included here are the specimens referred by Marshall (1987) to "Gaylordia doelloi".

Description of the skull and upper dentition. The specimen DGM 329-M is deformed because of lateral compression; the skull is broken anteriorly to the canines and behind the lacrimals. The rostrum includes maxillae, palatines, nasals, anterior part of frontals, and lacrimals (Figure 2). The infraorbital foramen is large and located in the maxilla above the anterior root of $\mathrm{P} 3$ (Figure 2A); the infraorbital canal is wide and the maxillary foramen opens into the anterior region of the orbit, where it is surrounded by the maxilla and the lacrimal (Figure 2B). Palatines are flat and, judging from the left one, palatal vacuities are absent. The maxillary-frontal contact is broad, much wider than in didelphoids. The nasals are posteriorly expanded, reaching their maximum width at the level of the M1. On the left side of the skull the lateralmost suture with the frontal bone can be observed, which is aligned with the lacrimal foramen (Figure 2A).

The left lacrimal is better preserved. Sutures with the maxilla, frontal, and part of the palatine are visible, but the ventral suture with the maxilla is difficult to distinguish. There is a single, large lacrimal foramen, opening inside the orbit (Figure 2B). In contrast, in most didelphids there are usually two separate openings exposed on the face (but see Voss \& Jansa, 2009). There is no evidence of a lacrimal tubercle. The anterior edge of the orbit, which is almost coincident with the lacrimal-maxillary suture, is placed dorsal to the middle part of M2 (Figures 2A,D). This condition resembles that of Herpetotherium according to Sánchez-Villagra et al. (2007) rather than that of Pucadelphys, where it is aligned dorsally with M1. 

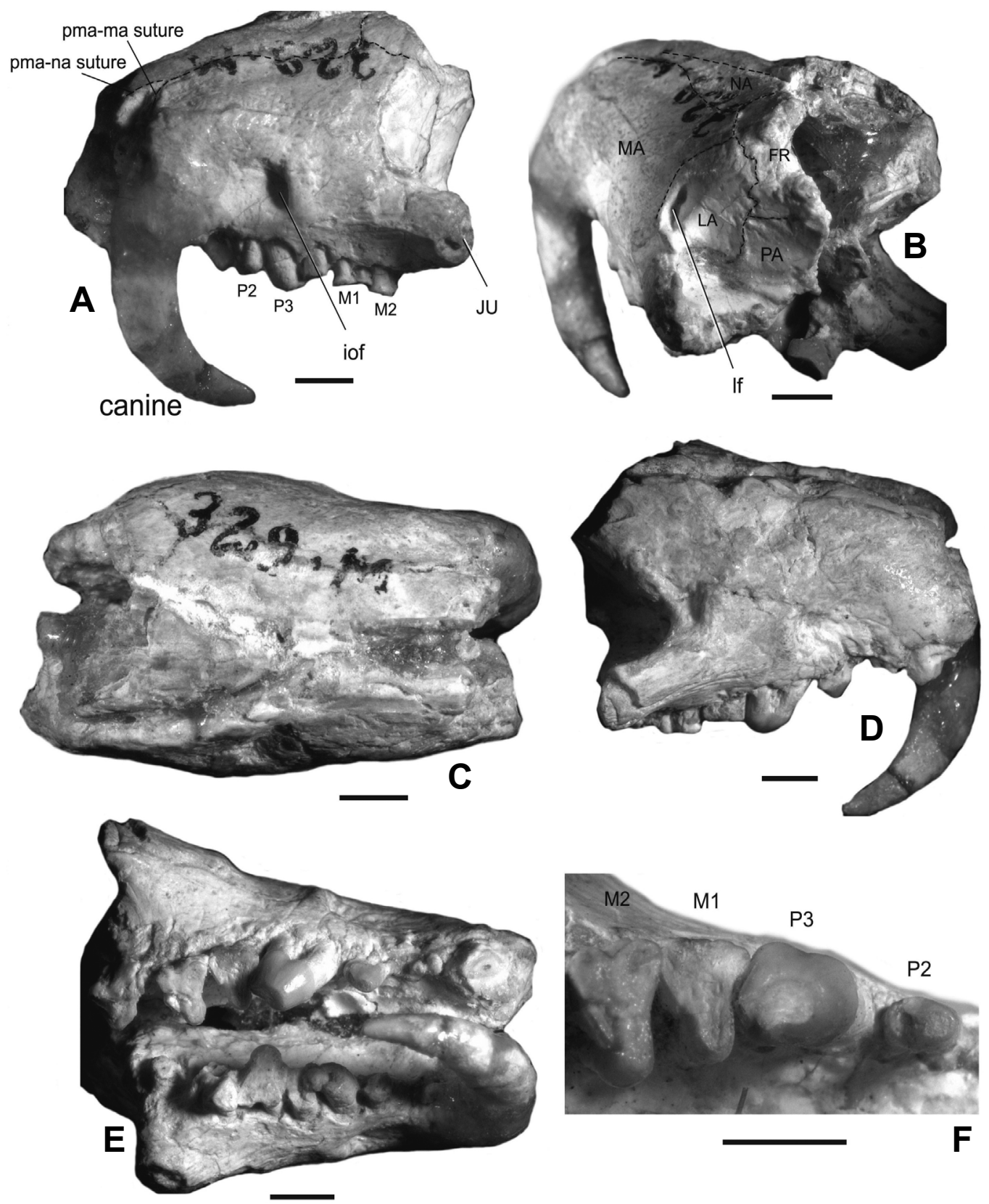

Figure 2. Gaylordia macrocynodonta, a partial skull, DGM 329-M (holotype). A, left lateral view; B, lateral oblique view; C, dorsal view; D, right lateral view; E, palatal view; F, left P2-M2 teeth in occlusal view. Abbreviations: iof, infraorbital foramen; If, lacrimal foramen; FR, frontal; JU, jugal; LA, lacrimal; PA, palatine, Pma, premaxilla; ma, maxila; na, nasal. For other abbreviations see Material and Methods. Scale bars $=2 \mathrm{~mm}$.

Based on what is preserved on the left side of the skull and in the lower dentition (see below), the post-incisor dental formula of Gaylordia macrocynodonta is $\mathrm{C} 1 / \mathrm{c} 1$; $3 \mathrm{P} / 3 \mathrm{p} ; 4 \mathrm{M} / 4 \mathrm{~m}$. The single-rooted canine is very large, long, curved and laterally compressed. Measurements of left C: height, 5.80; width at base, 1.78; length at base 2.42. There is no diastema between the canine and P1. Short diastemata, nearly equal in length, occur between $\mathrm{P} 1$ and $\mathrm{P} 2$, and $\mathrm{P} 2$ and P3 (Figures 2E,F). There is no diastema between P3 and M1 (Figure 2F). The best preserved molars are the left M1-
2, although they are much worn; they are wider than long (Figures 2E,F).

Dentary and lower dentition. The dentary of the type specimen is badly preserved (Figures 3A,B). The mandibular symphysis is unfused, and extends backwards to a point below the anterior root of $\mathrm{p} 3$ (Figure 3A). A large mental foramen, probably representing the anterior, is located below $\mathrm{p} 2$ (Figure 3B). The posterior foramen is not preserved. The $\mathrm{P} 3$ is inflated, ovate in outline and has a large posterior accessory cusp. The M1 is worn and very small in relation to $\mathrm{p} 3$. 
A partial dentary (MCT 2385-M) with $\mathrm{m} 1-2$ is more robust than that of the type specimen (Figures 3C-E), probably reflecting intraspecific variation. It is very deep below the molars $(4.66 \mathrm{~mm})$, being comparatively deeper than that of the type specimen $(4.10 \mathrm{~mm})$ and also that of the new species of Gaylordia $(4.40 \mathrm{~mm})$. The retromolar space between the last molar and the anterior edge of the ascending process is short, corresponding to less than half of $\mathrm{m} 4$ length.

\section{Gaylordia mater sp. nov.}

(Figures 4-8; Table 1)
Holotype. DGM 810-M, a partial right dentary with complete m2-4.

Hypodigm. The type and MCT 2383-M (DGM 644-M), incomplete left dentary with m1-2 and m4; MCT 2384-M (DGM 645-M), incomplete left dentary with p3, m1-2, incomplete $\mathrm{m} 3$ and complete $\mathrm{m} 4$; MCT 2386-M, incomplete right dentary with $\mathrm{m} 3$ and alveoli of $\mathrm{p} 3$ (only the posterior alveolus is complete), $\mathrm{m} 1, \mathrm{~m} 2$ and $\mathrm{m} 4$; MCT 2387-M, incomplete right dentary with complete $\mathrm{p} 3$ and $\mathrm{m} 1$, alveoli of $\mathrm{p} 2$, and $\mathrm{m} 2$; MCT 2774-M, complete left $\mathrm{m} 4$; MCT 2775 $\mathrm{M}$, incomplete right $\mathrm{m} 3$; MCT 2776-M, complete right $\mathrm{m} 3$;

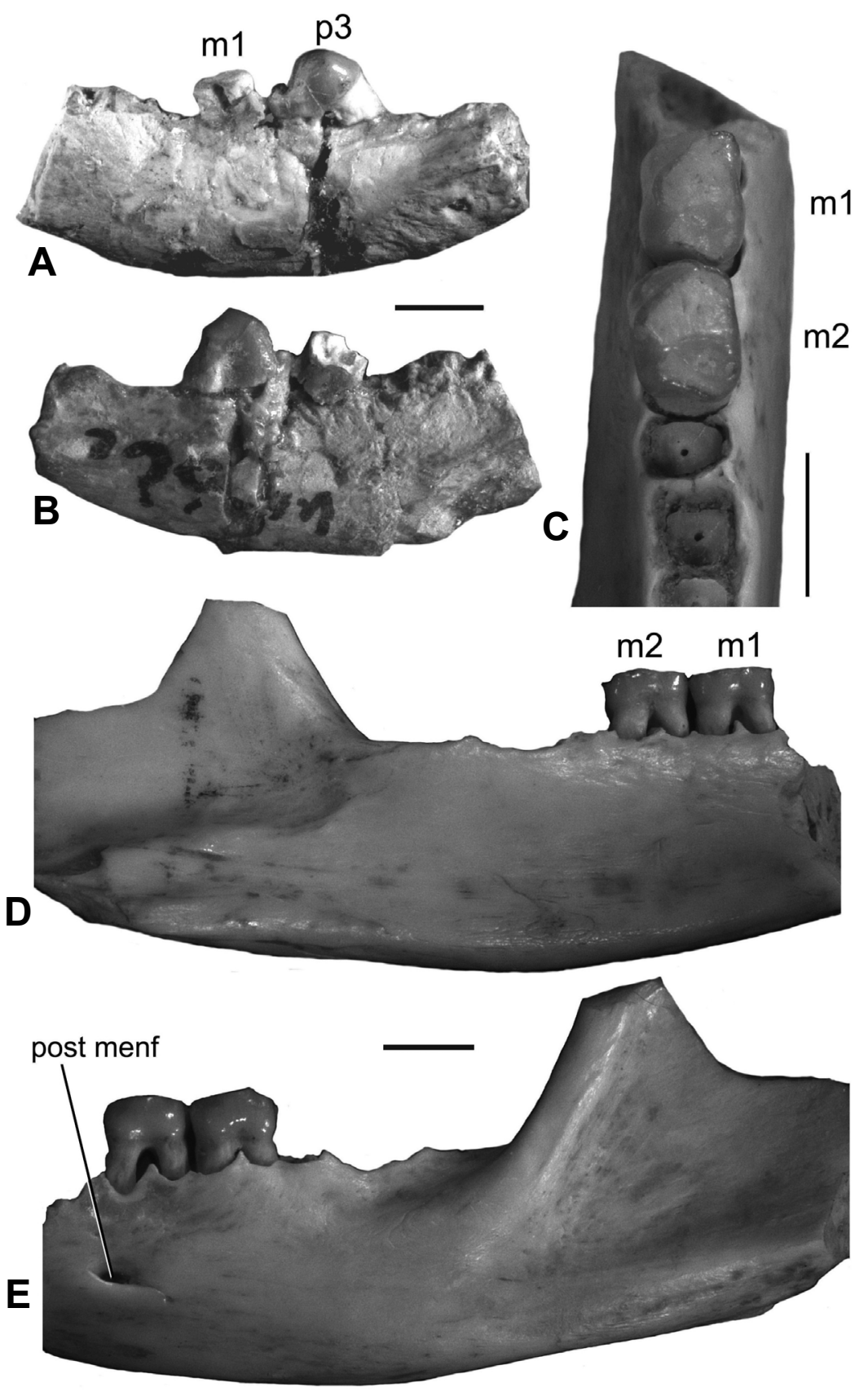

Figure 3. Gaylordia macrocynodonta, partial dentaries. A-B, DGM 329-M (holotype). A, in lingual view; B, in labial view. C-E, MCT 2385-M. C, m1-2 in occlusal view; D, dentary in lingual view; E, dentary in labial view. Abbreviation: post menf, posterior mental foramen. For other abbreviations see Material and Methods. Scale bars $=2 \mathrm{~mm}$. 
Table 1. Measurements $(\mathrm{mm})$ of upper and lower molars of Gaylordia macrocynodonta and Gaylordia mater sp. nov. Abbreviations: see Material and Methods.

\begin{tabular}{|c|c|c|c|c|c|c|c|c|c|c|c|c|c|}
\hline & LP2 & WP2 & LP3 & WP3 & LM1 & WM1 & LM2 & WM2 & LM3 & WM3 & LM4 & WM4 & \\
\hline \multicolumn{14}{|c|}{ Gaylordia macrocynodonta } \\
\hline DGM 329-M & 1.38 & 0.80 & 2.06 & 1.60 & 1.78 & 1.98 & 1.68 & 2.14 & & & & & \\
\hline \multicolumn{14}{|c|}{ Gaylordia mater sp. nov. } \\
\hline МCT 2777-M & & & & & & & 2.12 & 2.52 & & & & & \\
\hline MCT 2778-M & & & & & & & 2.10 & 2.52 & & & & & \\
\hline МCT 2779-M & & & & & & & 2.19 & 2.56 & & & & & \\
\hline MCT 2780-M & & & & & & & & & 1.96 & 2.76 & & & \\
\hline \multirow[t]{2}{*}{ MCT 2781-M } & & & & & & & & & 1.97 & - & & & \\
\hline & Lp2 & Wp2 & Lp3 & Wp3 & Lm1 & Wm1 & $\operatorname{Lm} 2$ & $\mathrm{Wm} 2$ & Lm3 & $\mathrm{Wm} 3$ & $\mathrm{Lm} 4$ & $\mathrm{Wm} 4$ & Lm1-4 \\
\hline \multicolumn{14}{|c|}{ Gaylordia macrocynodonta } \\
\hline DGM 329-M & & & 2.48 & 1.32 & & & & & & & & & \\
\hline MCT 2385-M & & & & & 2.04 & 1.42 & 2.06 & 1.52 & & & & & \\
\hline MN 2882-V & 1.24 & 0.75 & 1.60 & 1.00 & 1.45 & 1.00 & 1.48 & 1.02 & 1.48 & 1.02 & 1.46 & 0.98 & 5.60 \\
\hline \multicolumn{14}{|c|}{ Gaylordia mater sp. nov. } \\
\hline DGM 810-M & & & & & & & 2.10 & 1.42 & 2.04 & 1.48 & $1.90^{*}$ & 1.34 & \\
\hline МCT 2386-M & & & & & & & & & 1.88 & 1.38 & & & \\
\hline MCT 2383-M & & & & & 1.94 & 1.37 & 2.12 & 1.44 & & & 1.94 & 1.28 & 7.44 \\
\hline MCT 2384-M & & & 1.70 & 1.13 & 1.95 & 1.36 & $2.10^{*}$ & 1.44 & & & 2.00 & 1.26 & 7.80 \\
\hline MCT 2387-M & & & 1.72 & 0.93 & 1.95 & 1.37 & & & & & & & \\
\hline MCT 2474-M & & & & & & & & & & & 1.92 & 1.50 & \\
\hline МCT 2775-M & & & & & & & & & 2.25 & 1.66 & & & \\
\hline МCT 2776-M & & & & & & & & & 2.01 & 1.45 & & & \\
\hline
\end{tabular}

MCT 2777-M, complete right M2; MCT 2778-M, incomplete left M2; MCT 2779-M, incomplete right M2; MCT 2780-M, complete left M3; MCT 2781-M, incomplete right M3.

Etymology. -mater; Latin for "mother"; in reference to the more generalized morphology of its molars as compared with the type species of the genus and closely related forms.

Locality and age. São José de Itaboraí, State of Rio de Janeiro, Brazil; Itaboraí Basin, early Eocene, Itaboraian SALMA.

Diagnosis. Small metatherian with an estimated body mass of $\sim 60.6-90.9$ g. Differs from Gaylordia macrocynodonta in its lack of a bulbous $\mathrm{p} 3$, which is smaller than the $\mathrm{m} 1$; dentary with slightly longer retromolar space ( half of $\mathrm{m} 4$ length), lower molars with the metaconid more transversally aligned with the protoconid, and talonid anteroposteriorly less compressed.

Description. Lower dentition: The p3 (DGM 2384 and 2387$\mathrm{M})$ is smaller than the $\mathrm{m} 1$, slightly inflated, and presents a low and broad posterobasal heel (Figures 5A-B). The $\mathrm{m} 1$ is heavily worn in 2387-M and DGM 2384 (Figures 5B,D). The trigonid is slightly longer than the talonid, but it is equal in width, and the paraconid is placed less lingually than the metaconid (Figures $5 \mathrm{~B}, \mathrm{D}, \mathrm{H}$ ). The $\mathrm{m} 2$ (DGM 810-M) (Figure 4C) exhibits the trigonid anteroposteriorly compressed, higher crowned and wider in relation to the talonid. Although it is slightly inclined posteriorly, the protoconid is not posteriorly located in relation to the metaconid. The paraconid and the metaconid are lingually placed, and are close to each other. The anterior cingulid is short, but anteriorly salient. The talonid is not reduced in width but anterorposteriorly compressed, being shorter than the trigonid. The entoconid is small, conical and located close to the metaconid. The preentocristid is absent. The hypoconulid is moderately sized and is located at the posterolingual corner of the tooth. The cristida obliqua is short and ends slightly labial to the postprotocristid notch. The posthypocristid is longer than the prehypocristid. The postcingulid is present but vestigial. The $\mathrm{m} 3$ (DGM 810 M) differs from $\mathrm{m} 2$ in having the protoconid even more transversely aligned with the metaconid, less developed anterior cingulid and more developed posterior cingulid (Figure 4C). The specimen MCT 2776-M is better preserved in relation to the holotype (Figures 6A-C); a remarkable feature of this tooth is that the hypoconulid is stronger and higher than the entoconid. In occlusal view, the metaconid is circular in outline. The m4 (DGM 810-M; Figure 4C) lacks the lingual and distal parts of the talonid. It differs from $\mathrm{m} 3$ in having a slightly smaller trigonid and a less labially salient hypoconid (Figure 4C). A small labial cingulid is 

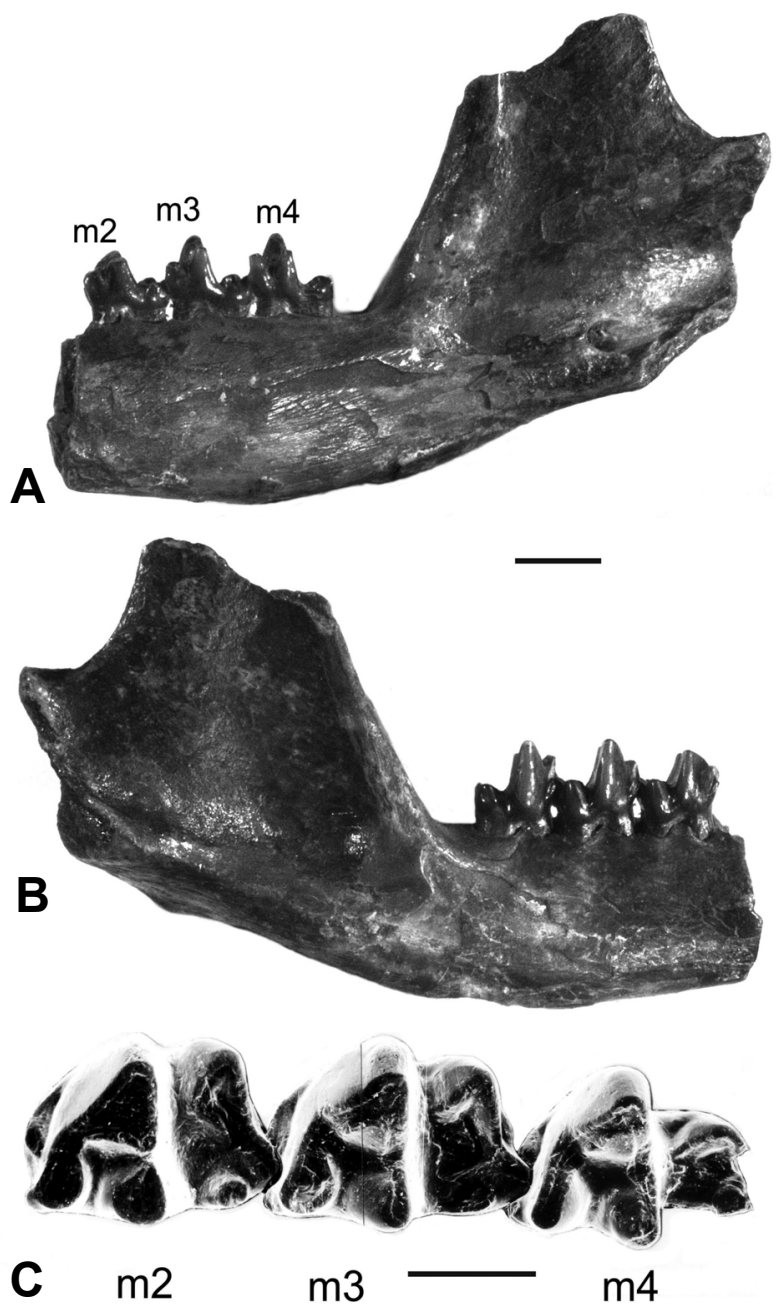

Figure 4. Gaylordia matersp. nov., DGM 810-M (holotype). A, partial dentary in lingual view; B, partial dentary in labial view; C, m1-m3 in occlusal view. Abbreviations: see Material and Methods. Scale bars: A, $B=2 \mathrm{~mm}, C=1 \mathrm{~mm}$.

present. The $\mathrm{m} 4$ in the specimen MCT 2383-M (Figures $5 \mathrm{E}, \mathrm{F}, \mathrm{H})$ is complete and bears a talonid that is not greatly reduced as in the other species of the genus; the talonid bears a well-developed hypoconulid, which is located at the posterolingual corner of tooth. The posterior cingulid is not reduced. The posthypocristid is less transversely oriented with respect to the long axis of the tooth, extending to a point near the postero-lingual corner, and connects with the hypoconulid at its base.

Dentary: The deepest part of the dentary is developed below the m4 (Figures 4A,B). Unlike "Gaylordia doelloi" and G. macrocynodonta, a well-developed retromolar space, corresponding in size to half the length of $\mathrm{m} 4$, is present (Figures 4A,B; 5A,E,F). The anterior edge of the coronoid process forms an angle of approximately $120^{\circ}$ with respect to the horizontal axis of the dentary. MCT 2383-M has a quite large mandibular foramen located nearer to the angular process than to the anterior base of the condyle (Figures 5A,E). The mandibular condyle is placed well above the alveolar margin (Figures 5E,F). The angular process is medially inflected
(Figure 5G). There are two mental foramina: one below the anterior root of the $\mathrm{p} 2$ and the posterior one below the posterior half of $\mathrm{m} 1$ (Figures 5A,F). In MCT 2387-M the posterior foramina is located below the anterior root of $\mathrm{m} 2$ (Figure 5C).

Upper dentition: MCT 2777-M has a shallow ectoflexus and the stylar shelf is moderate in width (Figures 7A,B). The tooth is worn, but exhibits a large and ovate $\mathrm{StC}$, which is located inside the stylar shelf. Both the $\mathrm{StB}$ and $\mathrm{StC}$ are placed closer to each another than StD. The presence of a metaconule is suggested by the convex postprotocrista at its distal end. The MCT 2779-M (Figure 7C) has strongly worn stylar shelf and talon, especially on $\mathrm{StC}$ region and postmetacrista. MCT 2778-M (Figures 8A,B) is the only tooth without advanced wear, lacking due to breakage only the StC. A small and pointed cuspule is present on the labial margin of the tooth, immediately labial to the broken region of StC. The ectoflexus is shallow. The well-preserved centrocrista is slightly v-shaped and weakly invasive labially. The trigon cusps are high and with sharp crests. The metacone is much larger than the paracone. Both these cusps are laterally compressed. The base of the metacone extends further lingually than that of the paracone. The preparacrista ends labially at the anterolingual face of StB. The para- and metaconule are very compressed laterally. The anterior cingulum is shallow. The M3 (MCT 2780-M and MCT 2781-M) is transversally wider than M1-2. The $\mathrm{StB}$ is similar in size to $\mathrm{StC}$. The $\mathrm{StC}$ is large, ovate, and slightly more compressed than in M2 (Figures 7D-F). The StD is less robust than in M2, and is connected to StC by a low crest. The ectoflexus is better developed than in M1 and M2, with the deepest point between StC and StD. The StA is proportionally smaller than in M1 and M2. The conules are vestigial.

\section{PHYLOGENETIC ANALYSIS}

Two phylogenetic analyses presented here resulted in distinct topologies. The first topology (987 steps, CI 0.3435 , RI 0.6482, RC 0.2226) resulted from a matrix version with craniodental + petrosal type I characters (Ladevèze \& Muizon, 2010), showing Gaylordia occupying a sister taxon position to the pucadelphyids (Figure 9A). When the maximum parsimony analysis included data on the craniodental and petrosal type VI (Ladevèze \& Muizon, 2010), four most parsimonious trees were obtained (988 steps, CI 0.3431, RI 0.6475, RC 0.2222), and the strict consensus tree recovered Gaylordia in a politomy with pucadelphyids, and Herpetotherium + Marsupialia (Figure 9B). The strict consensus of two trees from the first matrix data is better resolved than the second matrix analyzed (Figure 9A). All main clades obtained in these analyses are similar to those obtained by Beck (2012) and Beck et al. (2014, 164: fig. 17A).

\section{DISCUSSION}

Since the description of the type materials of Gaylordia macrocynodonta by Paula Couto (1952), details of the occlusal surface of its upper molars were unknown. The 


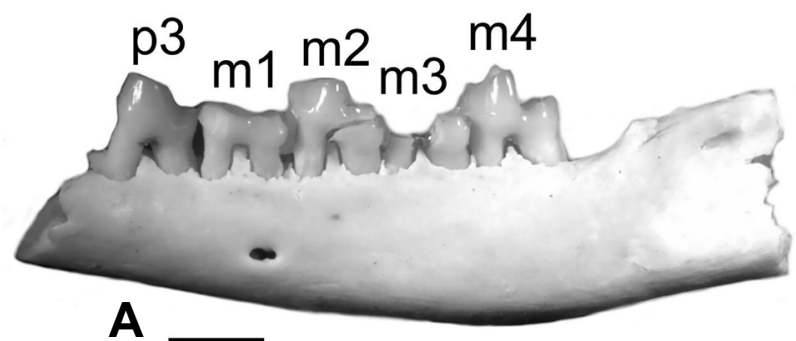

A

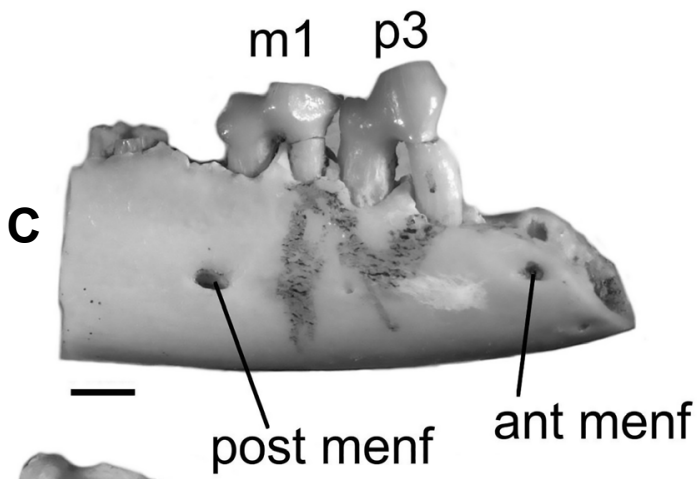

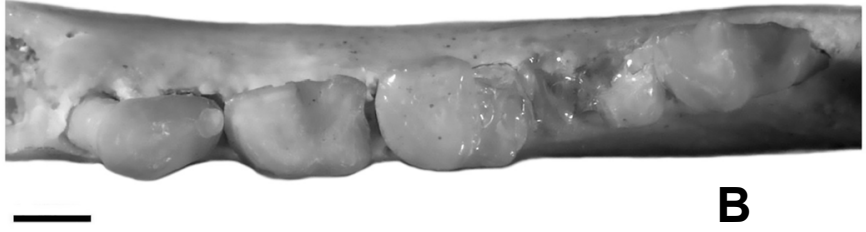

D
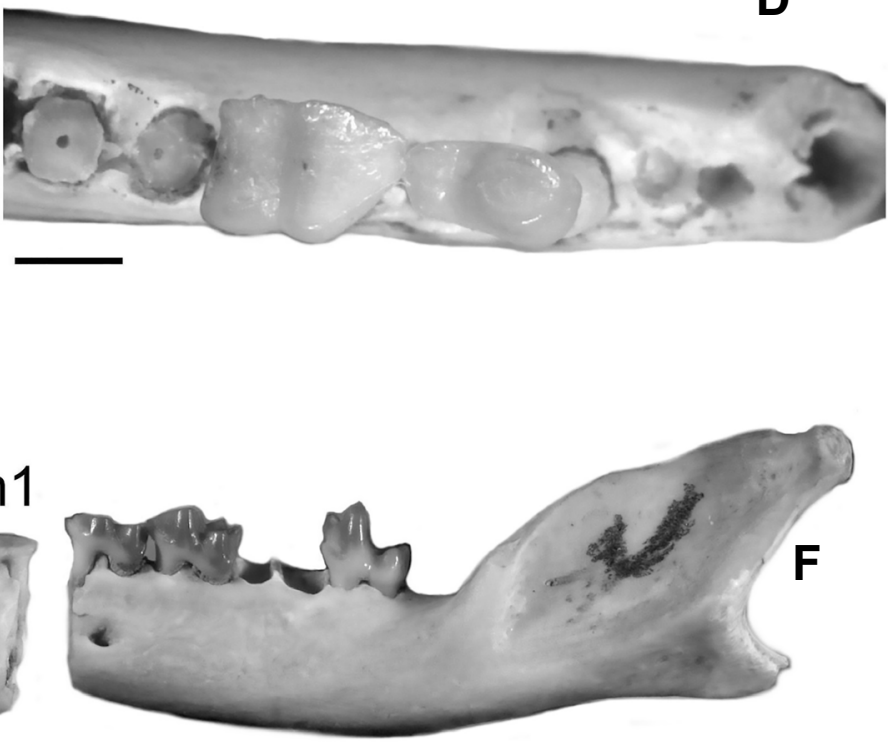

$\mathbf{F}$

H

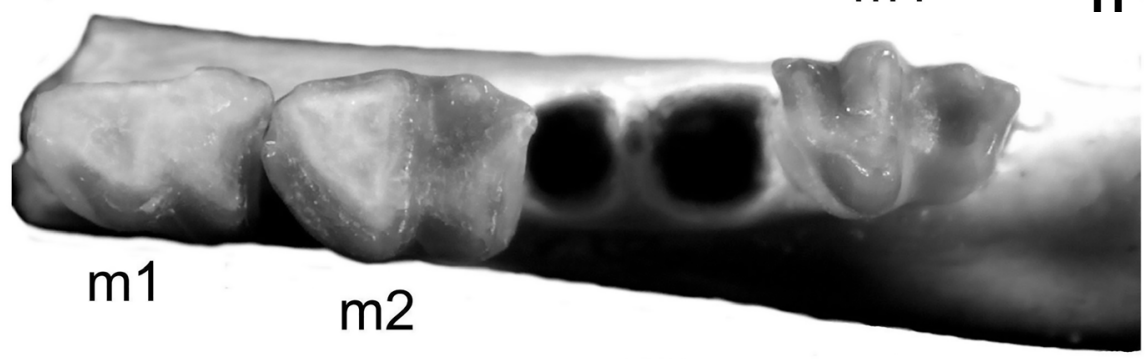

Figure 5. Gaylordia mater sp. nov., dentaries and lower dentition. A, MCT 2384-M, labial view; B, MCT 2384-M, occlusal view; C, MCT 2387M, labial view; D, MCT 2387-M, occlusal view; E, MCT 2383-M, lingual view; F, MCT 2383-M, labial view; G, MCT 2383-M, posterior view; H, MCT 2383-M, occlusal view. Abbreviations: ant menf, anterior mental foramen; post menf, posterior mental foramen; anp, angular process. For other abbreviations see Material and Methods. Scale bars: A,E-F $=2 \mathrm{~mm} ; \mathrm{B}-\mathrm{D}, \mathrm{G}-\mathrm{H}=1 \mathrm{~mm}$.

new specimens here described reveal that G. mater sp. nov. has a well-developed $\mathrm{StC}$, at least on M2-3. In M2, the $\mathrm{StC}$ is robust, ovate in outline, and is located closer to $\mathrm{StB}$ than to StD. In M3 the StC is slightly more labiolingually compressed and is located more lingually. In both molars, the maximum depth of the ectoflexus locates labial to $\mathrm{StC}$, being probably related to very labially expanded metastylar areas. The M3 is anteroposteriorly less developed than M2, in such a way that the postmetacrista is nearly parallel to the transverse axis of the tooth. In both M2 and M3, the protocones are anteroposteriorly compressed (a feature that correlates with the moderate talonid reduction in the lower molars), the stylar shelf is moderately reduced and the centrocrista is V-shaped but poorly invasive. In the lower molars the trigonid is shorter than the talonid (from m2-m4), the entoconid is very small relative to the hypoconid, and the hypoconulid is larger than the entoconid.

In comparison with Gaylordia macrocynodonta, the new species $G$. mater sp. nov. exhibits some plesiomorphic characters. The anteroposterior compression of the talonid in 
Table 2. Body mass estimates for Gaylordia spp. discussed in the text. Abbreviations: see Material and Methods.

\begin{tabular}{|c|c|c|c|c|c|}
\hline & & $\begin{array}{c}\text { Equation } \\
\text { (from Gordon, 2003) }\end{array}$ & $\begin{array}{c}\text { Body mass Gaylordia } \\
\text { macrocynodonta, MCT } 2385\end{array}$ & $\begin{array}{c}\text { Body mass Gaylordia } \\
\text { macrocynodonta MN } 2882\end{array}$ & $\begin{array}{l}\text { Body mass Gaylordia } \\
\text { mater sp. nov.) }\end{array}$ \\
\hline \multirow[t]{6}{*}{ Didelphidae } & $\mathrm{m} 1 \mathrm{LxW}$ & $2.924+1.56 * \ln$ & 97.8 & 33.2 & 86.2 (MCT 2387) \\
\hline & $\mathrm{m} 2 \mathrm{Lx} \mathrm{W}$ & $2.557+1.629 * \ln$ & 82.8 & 25.2 & 76.5 (holotype) \\
\hline & m3 L x W & $2.581+1.564 * \ln$ & - & 25.2 & 74.4 (holotype) \\
\hline & m4 L x W & $2.77+1.503 * \ln$ & - & 27.3 & 62.6 (MCT 2383) \\
\hline & M2 L x W & $1.349+1.707 * \ln$ & - & - & 66.2 (MCT 2778) \\
\hline & M3 L x W & $1.35+1.638 * \ln$ & - & - & 61.3 (МCT 2780) \\
\hline \multirow{6}{*}{$\begin{array}{c}\text { Pooled sample } \\
\text { (Didelphidae and } \\
\text { Dasyuridae) }\end{array}$} & m1 LxW & $2.933+1.605 * \ln$ & 103.6 & 34.1 & 90.9 (МCT 2387) \\
\hline & $\mathrm{m} 2 \mathrm{~L} \times \mathrm{W}$ & $2.403+1.67 * \ln$ & 74.4 & 22.0 & 68.6 (holotype) \\
\hline & $\mathrm{m} 3 \mathrm{~L} \times \mathrm{W}$ & $2.363+1.635^{*} \ln$ & - & 20.8 & 64.7 (holotype) \\
\hline & m4 L x W & $2.681+1.564 * \ln$ & - & 25.6 & 60.6 (MCT 2383) \\
\hline & M2 L x W & $1.267+1.708 * \ln$ & - & - & 61.1 (MCT 2778) \\
\hline & M3 L x W & $1.356+1.66 * \ln$ & - & - & 64.0 (MCT 2780) \\
\hline
\end{tabular}
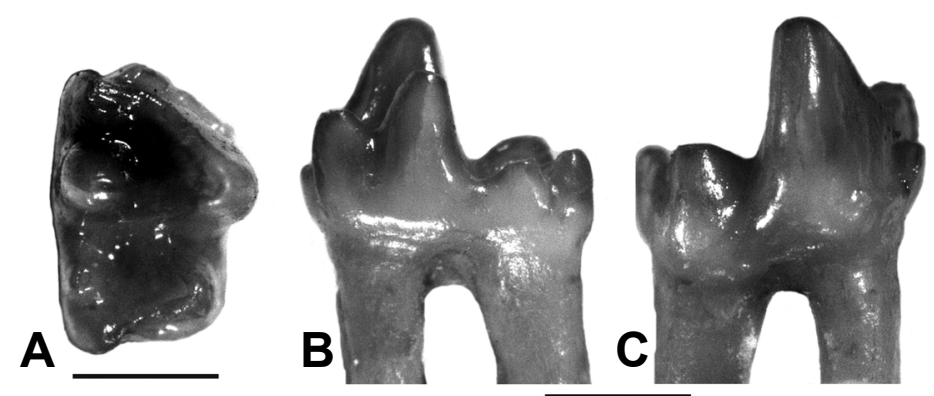

Figure 6. Gaylordia mater sp. nov., an isolated right m3, МСТ 2776-M. A, occlusal view; B, lingual view; C, labial view. Scale bars = $1 \mathrm{~mm}$.
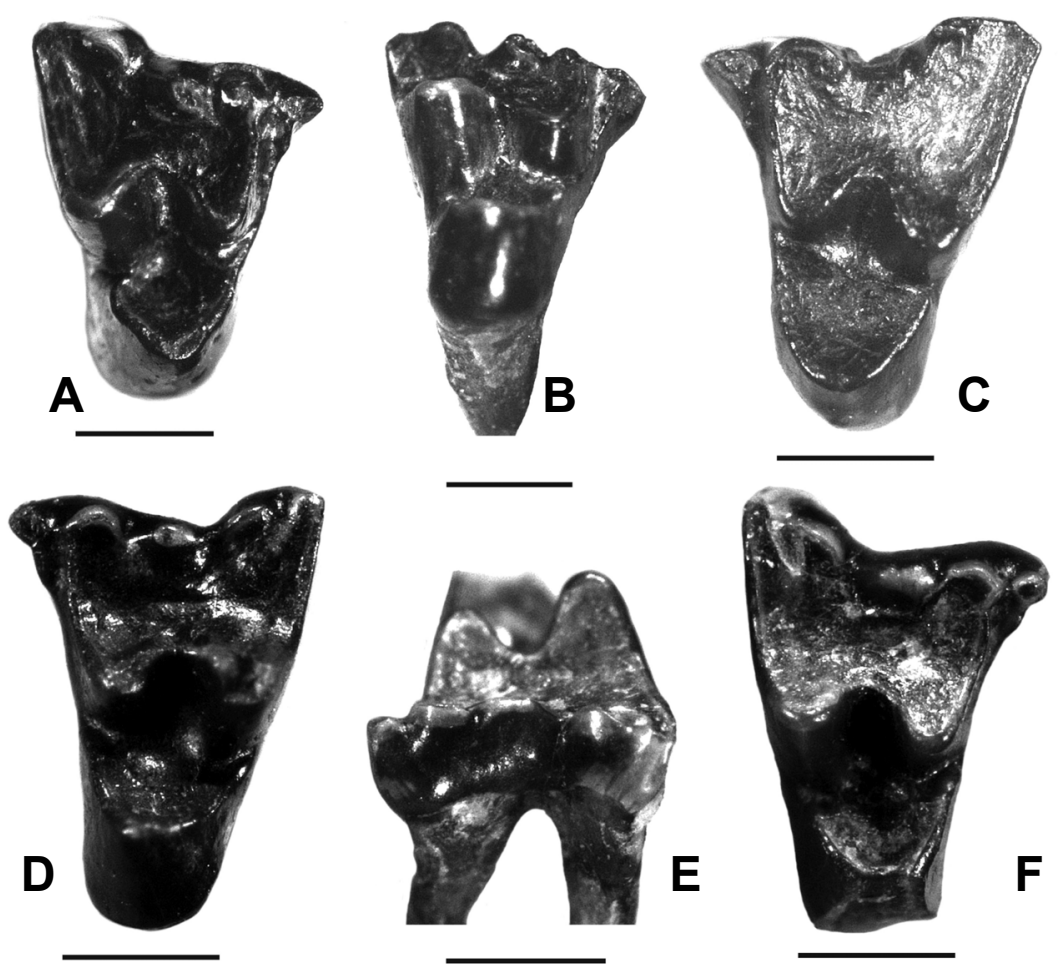

Figure 7. Gaylordia mater sp. nov., isolated upper molars. A, MCT 2777-M, M2 in occlusal view; B, MCT 2777-M, M2 in lingual view; C, MCT 2779-M, M2 in occlusal view; D, MCT 2780, M3 in occlusal view; E, MCT 2781, M3 in labial view; F, MCT 2781-M, M3 in occlusal view. Scale bars $=1 \mathrm{~mm}$. 


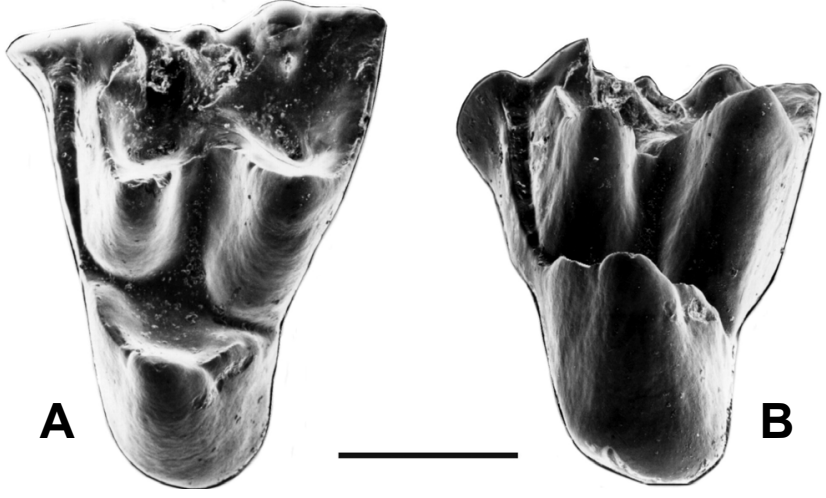

Figure 8. Gaylordia mater sp. nov., an isolated left M2 (MCT 2778-M). A, occlusal view; $B$, lingual view. Scale bar $=1 \mathrm{~mm}$.

G. mater is much less developed than in G. macrocynodonta. In $G$. mater sp. nov. the m1-3 trigonids exhibit a narrower anterior cingulid than in $G$. macrocynodonta. Another plesiomorphic feature in $G$. mater sp. nov. is related to the absence of the hypertrophied p3, which is present in $G$. macrocynodonta. In this regard, an interesting possibility would be that " $G$. doelloi" represents small individuals (or female specimens) of G. macrocynodonta. Regarding the molar morphology both species are inseparable. As seen above, skull is available only for G. macrocynodonta. However, dentaries are relatively well-represented in the other species of the genus. G. mater sp. nov. shows its dentaries as high as in G. macrocynodonta, and " $G$. doelloi” has dentaries which are lower than G. macrocynodonta. Marshall (1987) diagnosed " $G$. doelloi" as the smaller species of the genus (30\% smaller than the type species), with a p3 typically smaller relative to $\mathrm{m} 1$. However, a review of the MN 2882-V, described as "G. doelloi" by Marshall (1987), reveals that the p3 is larger than the $\mathrm{m} 1$. Thus, size is the only character that differentiates "G. doelloi" from the type species. In Recent marsupials, as small didelphids and dasyurids, differences in body size as well as in canine size represent sexual dimorphism (see Ladevèze et al., 2011; Fisher \& Cockburn, 2006). For example, hypertorphied canines in Monodelphis dimidiata are more characteristic of males than in females (Pine et al., 1985). Ladevèze et al. (2011) described a strong sexual dimorphism for Pucadelphys andinus as revealed by size differences in the skull, dentaries and canines, with males representing larger individuals. In conclusion, we regard size differences used up to now for the recognition of " $G$. doelloi", as very likely related to sex. Thus, we consider now $G$. doelloi as a junior synonym of $G$. macrocynodonta.

Putting aside previous studies including Gaylordia within the Didelphidae (Paula Couto, 1970; Marshall, 1987; Marshall et al., 1990), an alternative placement of this taxon was proposed by the phylogenetic study of Ladevèze \& Muizon (2010), that recovered Gaylordia inside the crown-group Marsupialia as a taxon closely related to Paucituberculata +Australidelphia clade. As shown above, a phylogenetic test utilizing craniodental and petrosal type I data (see Ladevéze
\& Muizon, 2010) recovered Gaylordia as a sister taxon to pucadelphyids (Fig. 9A). The idea that most or some Tiupampian and Itaboraian are closely related taxa have been advocated by Marshall et al. (1990), Muizon (1991), Muizon \& Brito (1993), Oliveira \& Goin (2006, 2011). These results reopen the question regarding the phylogenetic position of Itaboraian forms in relation to Paleogene forms and crown-group marsupials, which except Patene, are absent in denser sample taxa analyses (e.g. Sánchez-Villagra et al., 2007; Forasiepi, 2009; Horovitz et al., 2009; Beck, 2012; Beck et al., 2014; Engelman \& Croft, 2014). In several phylogenetic analysis pucadelphyids have been recovered as occupying a position near the crown-group, sometimes with Herpetotherium placed between them and Marsupialia, or as a sister group to Marsupialia (see e.g. Beck, 2012; Engelman \& Croft, 2014).

It should be noted that most potentially derived features observed in Gaylordia are present in some early Paleocene Tiupampian taxa such as the pucadelphyids Mizquedelphys, Incadelphys and Pucadelphys (Muizon, 1991; Goin, 2003), thus suggesting its belonging to, or close relation with, the Pucadelphyidae. Goin (2003) identified the following combination of features for Pucadelphyidae: retention of well-developed para- and metaconules, complete set of stylar cusps, StA and StB separated by a notch, expanded protocone, long preparacristae which, in the M3, is almost as long as the postmetacrista, weakly V-shaped centrocrista, and the labially (not posterolabially) oriented postmetacrista (especially in M3, where it is almost parallel to the preparacrista). Additionally, we note that at its deepest point, the ectoflexus is located between $\mathrm{StC}$ and $\mathrm{StD}$ on M2 and M3. On the lower molars, the hypoconulid is slightly larger than the entoconid, and the metaconid is aligned transversely to the protoconid (mainly on $\mathrm{m} 2$ and $\mathrm{m} 3$ ). Taking in account the incipient V-shaped centrocrista, expanded protocone, smaller entoconid relative to the hypoconulid, and the alignment of the protoconid and metaconid, we also consider Tiulordia, another Tiupampian genus, as a member of, or closely related to, the Pucadelphyidae. Muizon (1998) and later Ladevèze \& Muizon (2010) assigned Andinodelphys to the Pucadelphyidae. However, regarding the upper molar (holotype) Andinodelphys differs from the Pucadelphyidae in its straight instead of V-shaped centrocrista, smaller protocone, in that the deepest point of the ectoflexus is located labial to $\mathrm{StC}$, and in having a crested metaconule. The lower molar associated to Andinodelphys by Muizon (1991) agrees well with the Pucadelphyidae in its transversely aligned protoconid and metaconid, and hypoconulid larger than the entoconid. Oliveira \& Goin (2006) suggested that Andinodelphys is better compared to peradectids than to the didelphids. Pending a review of the type materials of Andinodelphys, we are cautious regarding its inclusion in the Pucadelphyidae. Another problematical taxon included within Pucadelphyidae is Mayulestes (see Engelman \& Croft, 2014). This genus originally was included by Muizon (1994) in its own family (Mayulestidae), within the Sparassodonta. In some phylogenetic studies 

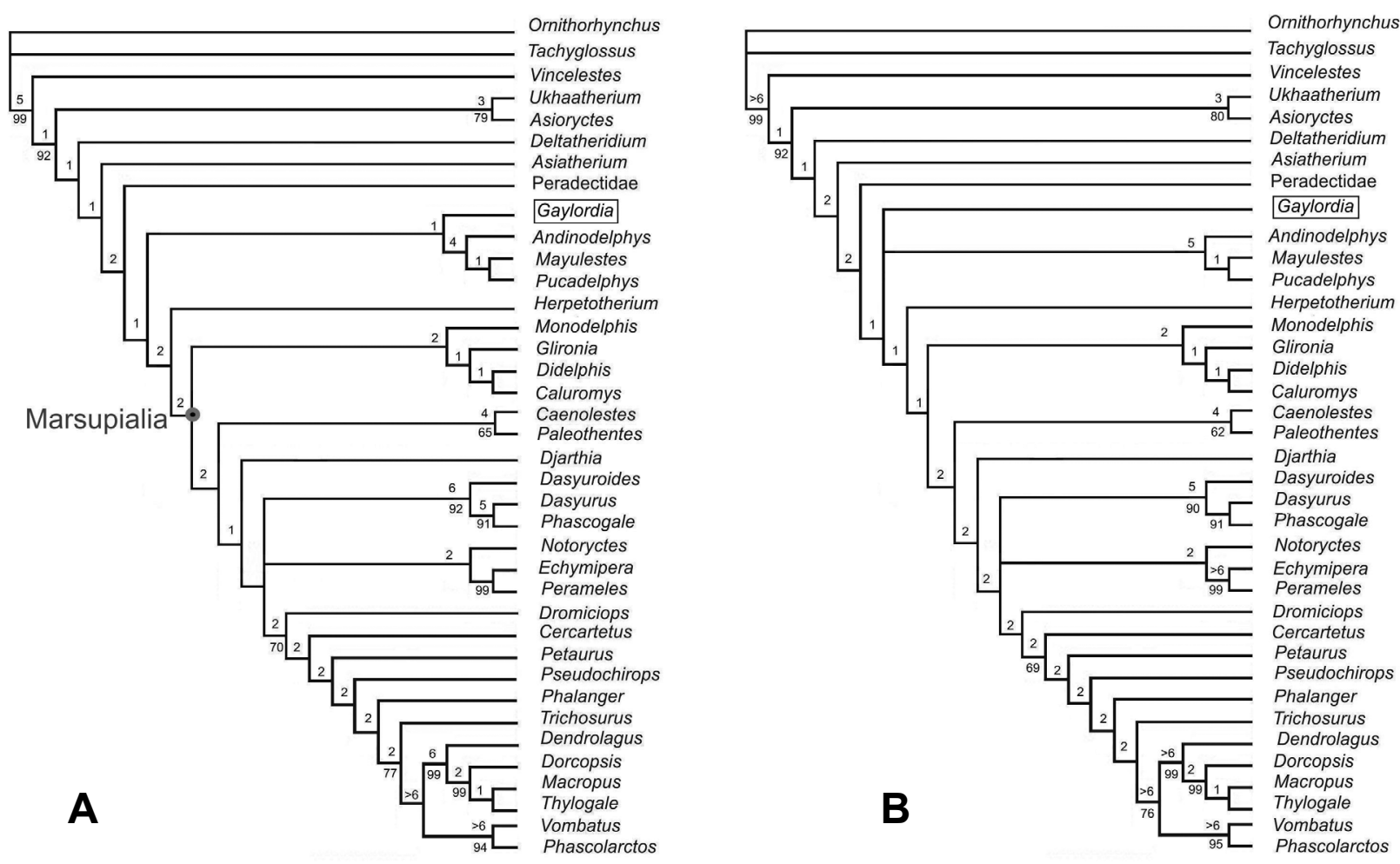

Figure 9. A, strict consensus cladogram of two trees obtained of the matrix with craniodental characters/petrosal type I. B, strict consensus cladogram of four trees obtained of the matrix with craniodental characters/petrosal type VI. Values to the upper left of each node represent Bremer supports, and numbers to the lower left represent bootstrap values (bootstrap values below 50 not shown).

Mayulestes has been frequently recovered as a sister taxon to Pucadelphys +Andinodelphys (e.g. Sánchez-Villagra et al., 2007; Horovitz et al., 2009; Forasiepi, 2009; Beck, 2012; Beck et al., 2014). Goin (2003) suggested that the molar morphology of Mayulestes fits well in the peradectid pattern, mainly in characters related to wide stylar shelf, stylar cusps moderately developed, preparacrista not reduced in length, paraconid not reduced or shifted antero-medially, and hypoconulids high. As stated before for Andinodelphys, we are cautious regarding inclusion of Mayulestes in the Pucadelphyidae.

Regarding dental adaptations, Marshall (1987) suggested that the presence of a bulbous P3/p3 in Gaylordia macrocynodonta constitutes an adaptation to crushing. Most upper and lower teeth identified as G. macrocynodonta have strongly worn and flattened occlusal surfaces. We also note that teeth belonging to G. mater sp. nov. exhibit a wear pattern which is similar to that of the type species (see e.g. Figure 5). The holotype of $G$. mater has stronger wear on $\mathrm{m} 2$ than on m3-4 (Figure 4), a feature also observable in MCT 2383$\mathrm{M}$ (Figures $5 \mathrm{~F}, \mathrm{H}$ ), where the $\mathrm{m} 1$ is the most strongly worn tooth, while $\mathrm{m} 3$ almost lacks any wear signal at all. These data suggest that the most crushing teeth are the anteriormost molars and the posteriormost premolars. Dental adaptations where $\mathrm{m} 1$ and $\mathrm{m} 2$ become heavily worn have been identified in carnivorous marsupials, especially in bone-eating and invertebrate-crushing consumers (see Jones, 2003).

\section{ACKNOWLEDGEMENTS}

E.V.O. acknowledges support from $\mathrm{CNPq}$ (process 307012/2010-7). We are indebted to D. Henriques (MN), A. Kellner (MN) and R.R. Machado (DNPM) for the opportunity to study the material described in this paper. F.J.G. thanks CONICET (PIP 0361). We also thank M. Woodburne and other two anonymous reviewers for the helpful corrections and constructive comments to an earlier version of this manuscript. We are also grateful to reviewers A. Abello and R. Beck for their constructive comments that improved the final manuscript.

\section{REFERENCES}

Beck, R. 2012. An ‘ameridelphian' marsupial from the early Eocene of Australia supports a complex model of Southern Hemisphere marsupial biogeography. Naturwissenschaften, 99:715-729. doi:10.1007/s00114-012-0953-x

Beck, R.; Travouillon, K.J.; Aplin, K.P.; Godthelp, H. \& M. Archer. 2014. The osteology and systematics of the enigmatic Australian Oligo-Miocene Metatherian Yalkaparidon (Yalkaparidontidae;Yalk aparidontia; ?Australidelphia; Marsupialia). Journal of Mammalian Evolution, 21:127-172. doi:10.1007/s10914-013-9236-3

Engelman, R.K. \& Croft, D.A. 2014. A new species of small-bodied Sparassodont (Mammalia, Metatheria) from the middle Miocene locality of Quebrada Honda, Bolivia. Journal of Vertebrate Paleontology, 34:672-688. doi:10.1080/02724634.2013.827118 
Fisher, D.O. \& Cockburn, A. 2006. The large-male advantage in brown antechinuses: female choice, male dominance, and delayed male death. Behavioral Ecology, 17:164-171. doi:10.1093/beheco/arj012

Forasiepi, A.M. 2009. Osteology of Arctodictis sinclairi (Mammalia, Metatheria, Sparassodonta) and phylogeny of Cenozoic metatherian carnivores from South America. Monografias del Museo Argentino de Ciencias Naturales, 6:1-174.

Forasiepi, A. \& Rougier, G. 2009. Additional data on early Paleocene metatherians (Mammalia) from Punta Peligro (Salamanca Formation, Argentina): comments based on petrosal morphology. Journal of Zoology Systematics Evolutionary Research, 47:391398. doi:10.1111/j.1439-0469.2008.00519.x

Goin, F. 2003. Early marsupial radiations in South America. In: M. Jones; C. Dickman \& M. Archer (eds.) Predators with pouches: the biology of carnivorous marsupials, CSIRO, p. 30-42.

Gordon, C.L. 2003. A first look at estimating body size in dentally conservative marsupials. Journal of Mammalian Evolution, 10:1-21. doi:10.1023/a:1025545023221

Horovitz, I.; Martin, T.; Bloch, J.I.; Ladevèze, S.; Kurz, C. \& Sánchez-Villagra, M.R. 2009. Cranial anatomy of the earliest Marsupials and the origin of opossums. PLoS ONE, 4:e8278. doi:10.1371/journal.pone.0008278

Huxley, J.S. 1880. On the application of the law of evolution to the arrangement of the Vertebrata, and more particular to the Mammalia. Proceedings of the Zoological Society of London, 43:649-662.

Jones, M.E. 2003. Convergence in ecomorphology and guild structure among marsupial and placental carnivores. In: M. Jones; C. Dickman \& M. Archer (eds.) Predators with pouches: the biology of carnivorous marsupials, CSIRO, p. 285-296.

Ladevèze, S. \& Muizon, C. 2010. Evidence of early evolution of Australidelphia (Metatheria, Mammalia) in South America: phylogenetic relationships of the metatherians from the Late Palaeocene of Itaboraí (Brazil) based on teeth and petrosal bones. Zoological Journal of the Linnean Society, 159:746-784. doi:10.1111/j.1096-3642.2009.00577.x

Ladevèze, S.; Muizon, C.; Beck, R.M.D.; Germain, D. \& Cespedes$\mathrm{Paz}, \mathrm{R} .2011$. Earliest evidence of mammalian social behaviour in the basal Tertiary of Bolivia. Nature, 474:83-86. doi:10.1038/ nature09987

Marshall, L.G. 1987. Systematics of Itaboraian (Middle Paleocene) age "opossum-like" marsupials from the limestone quarry at São José de Itaboraí, Brazil. In: M. Archer (ed.) Possums and opossums: studies in evolution, Surrey Beatty \& Sons and the Royal Zoological Society of New South Wales, p. 91-160.

Marshall, L.G.; Case, J. \& Woodburne, M.O. 1990. Phylogenetic relationships of the families of marsupials. In: H.H. Genoways (ed.) Current Mammalogy, Plenum Press, p. 433-505.

Medeiros, R.A. \& Bergqvist, L.P. 1999. Paleocene of the São José de Itaboraí Basin, Rio de Janeiro, Brazil: lithostratigraphy and biostratigraphy. Acta Geologica Leopoldensia, 22:3-22.

Muizon, C. 1991. La fauna de mamíferos de Tiupampa (Paleoceno Inferior, Formación Santa Lucia), Bolivia. Revista Técnica de Yacimientos Petroliferos Fiscales Bolivianos, 12:575-624.

Muizon, C. 1994. A new carnivorous marsupial from the Palaeocene of Bolivia and the problem of marsupial monophyly. Nature, 370:208-211. doi: 10.1038/370208a0

Muizon, C. 1998. Mayulestes ferox, a borhyaenoid (Metatheria, Mammalia) from the early Palaeocene of Bolivia. Phylogenetic and palaeobiologic implications. Geodiversitas, 20:19-142.
Muizon, C. \& Brito, I.M. 1993. Le bassin calcaire de São José de Itaboraí (Rio de Janeiro, Brésil): ses relations fauniques avec le site de Tiupampa (Cochabamba, Bolivie). Annales de Paléontologie, 79:233-269.

Oliveira, E.V. 1998. Taxonomia, filogenia e paleobiogeografia de marsupiais "poliprotodontes" do Mesopaleoceno da Bacia de Itaborai, Rio de Janeiro, Brasil. Programa de Pós-Graduação em Geociências, Universidade Federal do Rio Grande do Sul, Tese de Doutorado, 327 p.

Oliveira, E.V. \& Goin, F.J. 2006. Marsupiais do início do Terciário do Brasil: origem, irradiação e história biogeográfica. In: N.C. Cáceres \& E.L.A. Monteiro-Filho (eds.) Os Marsupiais do Brasil, Universidade Federal do Mato Grosso do Sul, p. 608-649.

Oliveira, E.V. \& Goin, F.J. 2011. A reassessment of bunodont metatherians from the Paleogene of Itaboraí (Brazil): systematics and age of the Itaboraian SALMA. Revista Brasileira de Paleontologia, 14:105-136. doi:10.4072/rbp.2011.2.01

Paula Couto, C. 1952. Fossil mammals from the beginning of the Cenozoic in Brazil. Marsupialia: Didelphidae. American Museum Novitates, 1567:1-26.

Paula Couto, C. 1962. Didelfídeos fósiles del Paleoceno de Brasil. Revista del Museo Argentino de Ciencias Naturales "Bernardino Rivadavia”, 112:135-66.

Paula Couto, C. 1970. News on the fossil marsupials from the Riochican of Brazil. Anais da Academia brasileira de Ciências, 42:19-34.

Pine, R.H.; Dalby, P.L. \& Matson, J.O. 1985. Ecology, postnatal development, morphometrics, and taxanomic status of the short-tailed opossum, Monodelphis dimidiata, an apparently semelparous annual marsupial. Annals of the Carnegie Museum, 54:195-231.

Sánchez-Villagra, M.; Ladevèze, S.; Horovitz, I.; Macrini, T.E.; Martin, J.E.; Moore-Fay, S.; Muizon, C.; Schmelzle, T. \& Asher, R.J. 2007. Exceptionally preserved North American Paleogene metatherians: adaptations and discovery of a major gap in the opossum fossil record. Biology Letters, 3:318-322. doi:10.1098/ rsbl.2007.0090

Swofford, D.L. 2002. PAUP*: Phylogenetic Analysis Using Parsimony (* and Other Methods). Version 4. Sinauer Associates, Sunderland, Massachusetts.

Szalay, F.S. 1994. Evolutionary history of the marsupials and an analysis of osteological characters. Cambridge, Cambridge University Press, $496 \mathrm{p}$.

Szalay, F.S. \& Sargis, E.J. 2001. Model-based analysis of postcranial osteology of marsupials from the Palaeocene of Itaboraí (Brazil) and the phylogenetics and biogeography of Metatheria. Geodiversitas, 23:139-302.

Woodburne, M.; Goin, F.J.; Raigemborn, M.S.; Heizler, M.; Gelfo, J.N. \& Oliveira, E.V. 2014. Revised timing of the South American early Paleogene land mammal ages. Journal of South American Earth Sciences, 54:109-119. doi:10.1016/j.jsames.2014.05.003

Voss, R.S. \& Jansa, S.A. 2009. Phylogenetic relationships and classification of didelphid marsupials, an extant radiation of New World metatherian mammals. Bulletin of the American Museum of Natural History, 322:1-177.

Received in August, 2014; accepted in January, 2015. 